\title{
Research of Social Skills of Children Who Attend to Kindergarten According to the Attitudes of Their Mothers*
}

\author{
Eda Gürbüz ${ }^{1}$, Binnaz Kıran ${ }^{2}$ \\ ${ }^{1}$ Expert Teacher, Turkey \\ ${ }^{2}$ Assoc. Dr., Mersin University, Department of Educational Sciences, Psychological Counseling and Guidance \\ Department, Yenisehir Campus, Mersin, Turkey \\ Correspondence: Binnaz Kıran, Mersin University, Department of Educational Sciences, Psychological Counseling and \\ Guidance Department, Yenisehir Campus, Mersin, Turkey.
}

Received: December 3, 2017

doi:10.11114/jets.v6i3.2831
Accepted: December 29, 2017 Online Published: February 17, 2018

URL: https://doi.org/10.11114/jets.v6i3.2831

\begin{abstract}
In this study, 5-6-year-old children who attend to kindergarten were researched if there is a difference in their level of social skills according to their mothers' attitudes, their gender, mother's employment status, the number of the children in the family, and to the caretaker. The study group was formed of 354 children who attend to kindergarten in the city centre of Mersin, Turkey and their mothers. "Social skills evaluation scale on children" developed by Ataş, Efe- Cinar and Tatar (2016) was used to evaluate social skills of the children and "parents' attitude scale" developed by Karabulut, Demir and Sendil (2008) was used to evaluate mothers' child bringing-up attitudes. Dual variance analyse was used to understand if children's social skill level becomes different or not according to their mothers' attitudes, their gender, employment status, the number of the children in the family, and to the caretaker. The source of the meaningful difference among groups as a result of the variance analyse was examined via Tukey HSD test. Level of significance in the research was accepted as 0,05 . According to research result, general social skills become different according to mothers' attitudes. The children whose mothers are democratic and permissive seem to have higher social skills than the children whose mothers are authoritative and protective.
\end{abstract}

Keywords: mother attitude, child, social skill, authoritative attitude, democratic attitude, permissive attitude and protective attitude

\section{Introduction}

Family has a decisive effect on individual's early childhood period as well as each growing period. Children express their emotion and behaviours without limits with the effect of the trust given by family environment. But through time, children develop organization skills by controlling themselves as they see that their parents don't accept their every behaviour. Actually, in the basis of the effect of the family on children growing and maturing, their first social experience is with the family and they gain their own socialness. The children learn the basic skills such as how to behave to others and how to behave when there is a problem by observing the behaviours in the family (Kol, 2016: 50).

Skill is defined as the possibility and the capacity of doing a desired thing or doing what is needed to gain it (Goodman, Joshi, Nasim and Tyler, 2015: 14). Ikesako and Miyamato (2015: 12), who make various studies and researches on development of social skill programs, define skill as personal features which interests at least one part of person's welfare and social development, can be evaluated and developed by educating.

Parental styles affect children's social, emotional and personal development significantly. Especially it is indicated that a stressful relationship creates pressure, and raise the anxiety on children and rise of parents' care and warm relationship affect them positively. Similarly, it is seen that there is a strong relation between various parents' attitudes and a lot of social behaviours of children such as concerns of children, depression, anxiety, extroversion, aggression (Ajilchi and Kargar, 2013: 450-451). Kiliç, Var and Kumandas (2015: 933) point that authoriser and authoritative parents' attitudes affect emotional management skills significantly.

*This article is produced from master approved by Cag University Institute of Social Sciences in 2017. 
Researches applied to different age groups show that parents' attitude affect social and emotional skills. Social skills which have complicated structures have important roles on forming peer relationships in their early childhood period. It is seen that weakness of these skills cause problems in starting and prolongation of relationships and make their peer relationships problematic. In the forming of lack of social skills and anti-social behaviours, educational factors, families, exposure of friends and peers, being in the biological transition period are effective (Brodeski and Hembrough, 2007: 9). It is seen that from these factors, parents' related attitude and behaviour patterns and their personal features affect the children and their self-expression skills which become a part of their socialness process (Kale, Cagdas and Tepeli, 255-256, 260). Rosli (2014: 94-97) hasn't faced a statistically meaningful relation between parents' attitude and behaviours and children's social and emotional behaviour problems and development features in his study which researches the effects of parenthood styles on children's social and emotional development in Muslim families in The USA.

Especially mothers who have intense relationships with their children are thought to be more effective on their children's development. Ajilci and Kargar (2013: 454) say that stress management has importance for mothers' setting a healthier and powerful communication with their children, because mothers' stressful and angry attitudes and behaviours create anxiety on children. Ambrose (2013: 30, 139-140) indicates that mothers' negative reaction against children cause emotion adjustment difficulties on children and lack of basic social skills such as cooperation, self-control, being confident, taking responsibility which are also known as pro-social skills. Naturally, mothers' positive and promotive attitudes and behaviours provide the development of basic skills such as cooperation, self-control, confidence. It is uttered that children' gender is also effective, like the attitudes of their parents on their social development, boys are generally effected by their fathers and girls by mothers (Okumura and Usui, 2010: 4). That's why it can be thought that gender is a dominant factor for the parent's effect on children.

As it can be seen in the literature, children's first social environment, family relationships and parents' attitudes and behaviours affect children's development and social skills. So, it is thought that it would be suitable to research the effects of the differences of mother attitudes on children's social skills in terms of various variables. In this frame, the main problem of this study and sub problems are identified below;

\subsection{Problem}

Do the 5-6-year-old children's, who attend to kindergarten, social skill level become different according to their mothers' attitudes, their gender, their mothers' marital status, employment status, the number of the children in the family and the caretaker?

\section{Method}

\subsection{Research Model}

The study was conducted in a descriptive relational scanning model. Relational studies search non-causal relations. The impact in these studies may be reciprocal since there is no control or change (Erkus, 2011).

\subsection{Study Group}

The study group of the research consisted of 354 children who attended to the kindergarten of the official schools in Mersin provincial centres of Turkey in 2016-2017 educational year and their mothers. In this study, easy-to-find sampling technique was used. "Easy-to-find sampling" is an example applied on individuals who are easy-to-reach, available, and want to participate in the study (voluntary) (Erkus, 2013: 122).

\begin{tabular}{llll}
\hline Mother attitudes & \multicolumn{2}{l}{ Children's social skill points } & $\mathrm{n}$ \\
\hline & $\mathrm{x}$ & $\mathrm{ss}$ & 112 \\
\hline Democratic & 321,2500 & 38,48727 & 83 \\
Authoritarian & 232,4819 & 52,67719 & 88 \\
Protective & 258,3523 & 65,42628 & 71 \\
Permissive & 318,2254 & 41,36361 & 354 \\
\hline Total & 284,1949 & 62,99601 & \\
\hline
\end{tabular}

\subsection{Data Collection Tools}

\subsubsection{Parent's Attitude Scale (PAS)}

Parental attitude scale was developed by Karabulut, Demir, and Sendil (2008) to measure parenting attitudes of parents who have children between 2-6 years of age. The scale is in likert style. In the scoring of the items, "It always happens" gets 5, "It is never like this" gets 1 point. The scores obtained from each dimension are calculated 
separately and one score is obtained for each dimension. Taking a high score means adopting the attitude that dimension represents.

\subsubsection{Social Skills Assessment Scale (SSAS)}

The Social Skill Assessment Scale (SSAS) was developed by Ataş, Efe, Cinar and Tatar (2016). Within the scope of the validity examination, since 7 sub-dimensions were defined as Relationship Initiation and Maintenance Skills (RIMS), Assertiveness Skills (AS), Feelings for Emotions (FE), Coping with Aggressive Behaviour and Instincts Skills (CABIS), Problem Solving Skills (PSS), Plan Making (PM) and Group Interaction and Ability to Do Work (GIADW) prior to the application, structural validity of SSAS was tested by Confirmatory Factor Analysis (CFA) of the actual application data. When the total scores of SSAS and sub-dimension scores were examined, it was found that the scale was valid and reliable (Ataş, et all. 2016: 74-75).

\subsection{Analysis of the Data}

First of all, the attitudes of the mothers were classified as democratic, authoritarian, protective and permissive. At the same time, children's social skills were organized according to their teacher's views. Whether the children's level of social skills differed according to the attitudes of the mother and the gender of the child, the marital status of the mother, the working status of the mother, the number of children in the family, the caretaker of the child was tested by Analysis of Variance. As a result of the variance analysis, the Tukey HSD test was used to find the source of the significant difference between the groups. Level of significance in the research was accepted as 0,05 .

\section{Findings}

Whether the children's level of social skills differed according to the attitudes of the mother and the gender of the child, the marital status of the mother, the working status of the mother, the number of children in the family, the caretaker of the child was examined and the findings were presented in Table1.

Table 1. Results of Variance Analysis on Children's Social Skill Scores According to the Attitudes of the Mothers and Various Variables

\begin{tabular}{|c|c|c|c|c|c|}
\hline Source of Variance & Sum of Squares & $\mathrm{Sd}$ & Mean Square & $\mathrm{F}$ & $\mathrm{p}$ \\
\hline \multicolumn{6}{|c|}{ According to children's gender } \\
\hline Mother attitudes & 503223,185 & 3 & 167741,062 & 66,376 & 000 \\
\hline Children's gender & 4338,092 & 1 & 4338,092 & 1,717 &, 191 \\
\hline \multicolumn{6}{|l|}{ Mother attitudes * } \\
\hline Children's gender & 6686,405 & 3 & 2228,802 & \multirow[t]{3}{*}{, 882} & \multirow[t]{3}{*}{451} \\
\hline Error & 874388,063 & 346 & 2527,133 & & \\
\hline Total & 29992309,000 & 354 & & & \\
\hline \multicolumn{6}{|c|}{ According to mother's marital status } \\
\hline Mother attitudes & 96262,952 & 3 & 32087,651 & 12,653 & 000 \\
\hline Mother's marital status & 14233,188 & 3 & 4744,396 & 1,871 &, 134 \\
\hline Mother attitudes * & 14714,980 & 8 & 1839,372 &, 725 & 669 \\
\hline \multicolumn{6}{|l|}{ Mother's marital status } \\
\hline Error & 859698,041 & 339 & \multicolumn{3}{|l|}{2535,982} \\
\hline Total & 29992309,000 & 354 & & & \\
\hline \multicolumn{6}{|c|}{ According to mother's employment status } \\
\hline Mother attitudes & 471013,652 & 3 & 157004,551 & 61,733 & 000 \\
\hline $\begin{array}{l}\text { Mother's employment } \\
\text { Mother attitudes } *\end{array}$ & 1,254 & 1 & 1,254 &, 000 & ,982 \\
\hline Mother's employment & 4101,968 & 3 & 1367,323 & \multirow[t]{3}{*}{, 538} & \multirow[t]{3}{*}{657} \\
\hline Error & 879975,507 & 346 & 2543,282 & & \\
\hline Total & 29992309,000 & 354 & & & \\
\hline \multicolumn{6}{|c|}{ According to the number of children in the family } \\
\hline Mother attitudes & 128946,416 & 3 & 42982,139 & 17,564 & 000 \\
\hline Children number & 11982,728 & 6 & 1997,121 &, 816 & ,558 \\
\hline \multicolumn{6}{|l|}{ Mother attitudes * } \\
\hline Children number & 50730,875 & 12 & 4227,573 & \multirow[t]{3}{*}{1,728} & \multirow[t]{3}{*}{060} \\
\hline Error & 812440,973 & 332 & 2447,111 & & \\
\hline Total & 29992309,000 & 354 & & & \\
\hline \multicolumn{6}{|c|}{ According to the child's caretaker } \\
\hline Mother attitudes & 411982,165 & 3 & 137327,388 & 54,016 & 000 \\
\hline Caretaker & 7,322 & 1 & 7,322 &, 003 & ,957 \\
\hline Mother attitudes * & 4364,817 & 3 & 1454,939 & 572 & 634 \\
\hline \multicolumn{6}{|l|}{ Caretaker } \\
\hline Error & 879654,597 & 346 & 2542,354 & & \\
\hline Total & 29992309,000 & 354 & & & \\
\hline
\end{tabular}


According to the results of the analysis in Table 1, there is a statistically significant difference between democratic (Avg: 321,25, ss:38, n:112), authoritarian (Avg: 232,49, ss:53, n:83), protective (Avg:258,35, ss:65, n:88), permissive (Avg: 318,22, ss:41, n:71) mother attitudes $\left[\mathrm{F}_{(3,354)}=503223,185 \mathrm{p}<.05\right]$. In other words, according to mothers' attitudes, children's social skills score averages are different. When the gender of the children, the marital status of the mother, the mother's working and not working, the number of the children in the house and the person who takes care of the child are examined, it is seen that there is no difference between the general social skills scores of the children. Furthermore, when the mother's attitudes and variables were taken together, no significant difference was found between them. When the source of the difference is examined according to the mother's attitudes, it is seen that the children of the democratic and permissive mothers have higher social skills than the children of the other mothers.

\section{Discussion}

According to the research result, 5-6 year old children's, who attend to kindergarten, social skills become different according to their mothers' attitudes. The children whose mothers are democratic and permissive have higher social skills than the children whose mothers have authoritative and protective attitudes. These results show that mothers' attitudes have an important role on children's social skills development which is an important development field. Parents' attitudes are one of the important variables which form the content of the relationship between parents and their children. Parents adjust their attitudes and behaviours according to their belief and values, their child-growing knowledge and many other factors (Abu-Rabia and Yaari, 2012: 171). Bierman and Furman (1984: 153-159) claim that social skills can be learnt. Learning by modelling is important for children's first experiences to become inside the family. Children's first development period occurs under the control and supervision of family which cause children to socialize by observing behaviours and roles in the family (Kol, 2016: 50). It is accepted that parents' positive and supportive attitudes have positive affect on children's social skills development in their social growing (Kilic, Var and Kumandas, 2015: 933). It is seen that especially oppressive and authoritative attitudes affect psycho-social development negatively and form a lot of social behaviour and emotions such as concern, depression, anxiety, extroversion and aggression (Ajilchi and Kargar, 2013: 450-451).

The problems because of the lack of social skills in children show themselves fairly in early periods. Moreover, these problems may cause permanent affect which will last for the whole life (Brodeski and Hembrough, 2007: 9). Although parents' effect on children is accepted as a result of role modelling, mothers' attitudes and behaviours has won a privileged place as children have interaction with the mother starting before the birth (Ambrose, 2013: 139-140). Mothers' negative attitudes towards children affect their social skills and emotional conditions negatively as child-mother relationships are mostly on emotional bases. But mothers' positive attitudes and behaviours towards children accelerate their basic skills development such as self-control and self-confidence (Ajilci and Kargar, 2013: 454).

According to Hasting and Rubin (1999: 736-736), Kandir and Alpan (2008: 37) and Ozkafaci (2012: 52-59) children whose parents are democratic and try to understand and listen to their children have higher social skills. Ambrose (2013: 127-128) who supports this idea indicates that mothers who have negative attitudes towards children cause their children's social skills weaken. According to Logan (2006: 50-53), warmness towards children at home affects their social skills development positively. Studies of Tösten, Han and Anik (2017: 172-173) and Kaya, Bozaslan and Genç, (2011: 1400-1401) point that democratic attitudes have positive effects. According to them, democratic attitudes explain $20 \%$ of the problem solving skills. When it is taken into account that families who have supportive attitudes show balanced and warm attitude, it can be said that the findings of these studies show similarity with this study which gives positive results in terms of democratic parents' attitudes.

Democratic and permissive parents attitudes can sometimes be studied as single or two different attitudes in the literature. Vijila, Thomas and Ponnusamy (2013:35) also studied the relationship between children's who are at puberty period social skills development and parents' attitudes and found that permissive parents attitudes affect children's social skills meaningfully positive. Scammell (2011: 54-55) indicates that mothers' attitudes and stress affect children's social skills. In another study which takes permissive and democratic attitudes separately, the effect of the parents' attitudes on mentally disabled children's social skills was studied. According to the mentioned study of Aydin and Sönmez (2014: 163), parents' democratic attitudes have positive affect on mentally disabled children's social skills.

In this study, there was no relationship between the other variables included in the survey and social skills. Especially, gender-related outcomes do not resemble the results of previous investigations. It is stated that the gender variable is influential; boys are more influenced by their fathers, and girls from their mothers. The main reason for this is that boys have a stronger relationship with their fathers than their mothers and girls have a stronger relationship with their mothers compared to their fathers (Okumura and Usui, 2010: 4). Therefore, gender matching in parental effects in children appears to be a dominant factor. According to Yilmaz (2014: 60-69), the age and gender of the students who go to the $6^{\text {th }}, 7^{\text {th }}$ and $8^{\text {th }}$ classes have an effect on the level of social skills. The study of Ozyürek and Ozkan (2015: 84) for 
adolescents also indicates that there is a relationship between the age of adolescents and social skills. However, these results are also seen to be limited. When social development and mother attitudes of 5-6-year old children are mentioned, it can be said that previous researches support the result of this research.

\section{Result}

According to the results of the research, the social skills of the children differ according to the attitudes of the mothers. Mothers who have democratic and permissive attitudes seem to have children with higher social skills than mothers with authoritarian and protective attitudes. The social skills differ according to the gender of the child, the marital status of the mother, the employment status, the number of children in the family, and the person who cares about the child. Due to the influence of parental attitudes on child development, it is seen that parents are involved in development programs applied in many parts of the world nowadays, as well as awareness raising activities for parents about developing attitudes (Boyd et al., 2005: 5). For this reason, attention should be paid to the inclusion of trainings for mothers into programs for improving children's social skills. In pre-school education, it is necessary to increase the number of activities for parents, especially mothers, to identify their children and spend more time together. In addition, the influence of mother attitudes on other developmental areas of children can be examined.

\section{References}

Abu-Rabia, S., \& Yaari, I. (2012). Parent's Attitudes and Behavior, the Learning Environment, and Their Influence on Children's Early Reading Achievement, Open Journal of Modern Linguistics, 2(4), Online, December, 170-179.

Ajilchi, B., \& Kargar, F. R. (2013). The Impact of a Parenting Skills Training Program on Stressed Mothers and Their Children's Depression Level, Procedia-Social and Behavioral Sciences, 84, 450-456. https://doi.org/10.1016/j.sbspro.2013.06.583

Ambrose, H. (2013). Young Children's Emotion Regulation and Social Skills: The Role of Maternal Emotional Socialization and Mother-Child Interactional Synchrony, University of Windsor Electronic Theses and Dissertations, Degree of Doctor of Philosophy at the University of Windsor, Ontario, CANADA.

Atas, A. T., Efe-Cinar, H. I., \& Tatar, A. (2016). Development of Social Skill Assessment Scale and Examination of Its Psychometric Properties, Turkish Psychological Counseling and Guidance Journal, 6(46), 71-85.

Bierman, K. L., \& Furman, W. (1984). The Effects of Social Skills Training and Peer Involvement on the Social Adjustment of Preadolescents, Child Development, 55(1), February, 151-162. https://doi.org/10.2307/1129841

Boyd, J., Barnett, W. S., Bodrova, E., Leong, D. J., \& Gomby, D. (2005). Promoting Children's Social and Emotional Development Through Preschool Education, National Institute for Early Education Research, New Brunswick, Canada.

Bozaslan, H. (2012). An Investigation of pre-service Teachers' Parents to the Epistemological Belief and Alternative Cognitive Properties (A Research in Harran University), Journal of European Education (JEE), 2(1), 28-40.

Brodeski, J., \& Hembrough, M. (2007). Improving Social Skills in Young Children, Saint Xavier University Chicago, Illinois, May, USA.

Demir, E. K., \& Sendil, G. (2008). Parent Attitude Scale (PAS), Turkish Psychological Articles, 11(21), 26-27.

Goodman, A., Joshi, H., Nasim, B., \& Tyler, C. (2015). Social and Emotional Skills İn Childhood and Their Long-Term Effects On Adult Life, A Review for The Early Intervention Foundation, 11th March 2015.

Hastings, P. D., \&Rubin, K. H. (1999). Predicting Mothers' Beliefs about Preschool-Aged Children's Social Behavior: Evidence for Maternal Attitudes Moderating Child Effects, Child Development, 70(3), 722-741. https://doi.org/10.1111/1467-8624.00052

Ikesako, H., \& Miyamoto, K. (2015). Fostering Social and Emotional Skills Through Families, Schools and Communities: Summary of International Evidence and Implication for Japan's Educational Practices and Research, OECD Education Working Papers, No. 121, OECD Publishing, Paris. https://doi.org/10.1787/5js075291wf0-en

Kale, U., Cagdas, A., \& Tepeli, K. (2013). Investigating the effect of parents' education level on skills of expressing emotions of primart 1st grade students, Journal of Research in Education and Teaching, 2(2), 254-262.

Kandir, A., \& Alpan, Y. (2008). The Effects of Parental Behavior on the Socio-Emotional Development in Preschool, Family and Society, 104(14), 33-38.

Kaya, A. H., Bozaslan, H., \& Genç, G. (2012). The Effect of the Parents' Attitudes on University Students' Problem-Solving Skills, Social Concerns and Academic Achievement, Dicle University Ziya Gökalp Education Faculty Journal, 18, 208-225. 
Kilic, S., Var, E. C., \& Kumandas, H. (2015). Effect of Parental Attitudes on Skills of Emotional Management in Young Adults, Procedia-Social and Behavioral Sciences, 191, 930-934. https://doi.org/10.1016/j.sbspro.2015.04.276

Kol, S. (2016). The Effects of the Parenting Styles on Social Skills of Children Aged 5-6, The Malaysian Online Journal of Educational Sciences, 4(2), 49-58.

Logan, J. N. (2006). Parental warmth and social skills in six to seven-year-old children, University of Massachusetts Amherst, Masters Theses 1911 - February 2014, USA.

Okumura, T., \& Usui, E. (2010). Do Parents' Social Skills Influence Their Children's Sociability?, Discussion Paper No. 5324, November, The Institute for the Study of Labor (IZA), Bonn, Germany.

Ozkafaci, A. A. (2012). Analyzing the relationship between mother's attitude towards growing up children and social skill level of the children, Istanbul Ar-El Uni. Institute of Social Sciences, Unpublished Master Thesis, İstanbul.

Rosli, N. A. (2014). Effect of Parenting Styles on Children's Emotional and Behavioral Problems Among Different Ethnicities of Muslim Children in the U.S., Dissertations (2009). 376, http://epublications.marquette.edu/dissertations_mu/376, Erişim: 01.07.2017

Scammell, J. (2011). Maternal Personality, Socialization Factors and the Relations with Children's Social Skills, University of Windsor Scholarship at U. Windsor, Electronic Theses and Dissertations, http://scholar.uwindsor.ca/cgi/viewcontent.cgi?article=1232\&context=etd

Tösten, R., Han, B., \& Anik, S. (2017). The Impact of Parental Attitudes on Problem Solving Skills İn High School Students, Universal Journal of Educational Research, 5(1), 170-174.

Vijila, Y., Thomas, J., \& Ponnusamy, A. (2013). Relationship between Parenting Styles and Adolescent Social Competence, IOSR Journal of Humanities and Social Science (IOSR-JHSS), 17(3), November- December, 34-36.

Yilmaz, F. (2014). A study on the relations between perceived parent attitudes of 6th - 8th grade middle school students and their social emotional learning skills, İstanbul Arel Uni. Institute of Social Sciences, Unpublished Master Thesis, İstanbul.

\section{Copyrights}

Copyright for this article is retained by the author(s), with first publication rights granted to the journal.

This is an open-access article distributed under the terms and conditions of the Creative Commons Attribution license which permits unrestricted use, distribution, and reproduction in any medium, provided the original work is properly cited. 